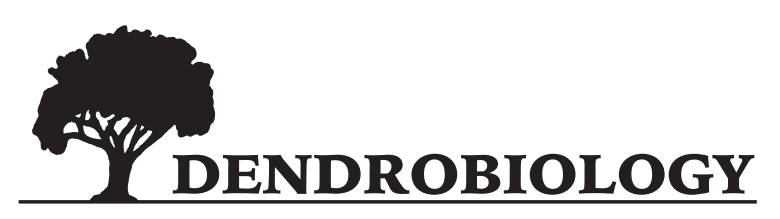

2021, vol. 85, 78-91

https://doi.org/10.12657/denbio.085.008

\begin{abstract}
Agustinus Murdjoko*, Dony Aristone Djitmau, Antoni Ungirwalu, Anton Silas Sinery, Rima Herlina Setiawati Siburian, Zulfikar Mardiyadi, Alfredo Ottow Wanma, Jimmy Frans Wanma, Alexander Rumatora, Wolfram Yahya Mofu, Descarlo Worabai, Nunang Lamaek May, Marthen Mathias Jitmau, George Alexander Frans Mentansan, Keliopas Krey, Ishak Musaad, Marhan Manaf, Yunus Abdullah, Hans Mamboai, Khristian Enggar Pamuji, Syafrudin Raharjo, Agustinus Kilmaskossu, Samsul Bachri, Nur-Alzair Nur-Alzair, Nithanel Mikael Hendrik Benu, Junus Tambing, Relawan Kuswandi, Lisna Khayati, Krisma Lekitoo
\end{abstract}

\title{
Pattern of tree diversity in lowland tropical forest in Nikiwar, West Papua, Indonesia
}

Received: 21 October 2020; Accepted: 4 February 2021

\begin{abstract}
Trees are significant components of ecosystems built by several widespread species. For instance, Papua forest is known to comprise abiotic and biotic elements. Also, certain plants have grown in popularity to a point where they are discovered almost everywhere. The purpose of this study, therefore, was to investigate tree diversity, distribution, and the importance of conservation. Data were collected in four locations using a total of 24 sample plots spread across Idoor, Karst, Persemaian, and Torembi, where seven, four, seven, and five plots were allocated, respectively. These forests formed a mixed natural plantation comprising 76 species from 35 families. Furthermore, Idoor and Karst generated the highest species diversity and varied significantly compared to Persemaian, while Torembi showed similarities with the other three locations. This condition formed three ecosystem communities across Persemaian, Karst, Idoor, and Torembi. Also, the composition of the dominant species showed variations at the seedling and sapling levels believed to structure the understory, while the pole and tree levels characterized the overstory. The total species status was described as critically endangered (CR) of two species, vulnerable (VU) of six species, least concern (LC) of 28 species, and data deficient (DD) species. Therefore, location management is advised to not only pay significant attention in terms of economic benefits but also ecological, including the provisions for ex-situ and in-situ conservation to support sustainable forest management.
\end{abstract}


Addresses: A. Murdjoko, D. A. Djitmau, A. Ungirwalu, A. S. Sineri, R. H. S. Siburian, Z. Mardiyadi, A. O. Wanma, J. F. Wanma, A. Rumatora, W. Y. Mofu, D. Worabai, N. L. May, Fakultas Kehutanan, Universitas Papua, Jalan Gunung Salju Amban, Manokwari Papua Barat 98314, Indonesia, e-mail: agustinus.murdjoko.papua@gmail.com; (1) AM https://orcid.org/0000-0003-4857-1884, (1) DAD https://orcid.org/0000-0001-6432-5523, (1) AU https://orcid.org/0000-0003-4125-208X, (1D) ASS https://orcid.org/0000-0002-0791-6375, (10) RHSS https://orcid.org/0000-0001-8005-804X, (1) ZM https://orcid.org/0000-0003-2161-8902, () AOW https://orcid.org/0000-0002-0090-6457, (D) JFW https://orcid.org/0000-0002-3450-5352, (1) AR https://orcid.org/0000-0003-1384-9022, (D) WYM https://orcid.org/0000-0001-8365-4891, (D) DW https://orcid.org/0000-0003-2721-1986, (1) NLM https://orcid.org/0000-0002-5862-0582

M. M. Jitmau, Pusat Penelitian Keanekaragaman Hayati (PPKH), Universitas Papua, Jalan Gunung Salju Amban, Manokwari Papua Barat 98314, Indonesia; (1) https://orcid.org/0000-0003-1988-526X,

G. A. F. Mentansan, K. Krey, I. Musaad, M. Manaf, Y. Abdullah, H. Mamboai, K. E. Pamuji, S. Raharjo, A. Kilmaskossu, S. Bachri, N. Nur-Alzair, Pusat Penelitian Lingkungan Hidup (PPLH) Universitas Papua, Jalan Gunung Salju Amban, Manokwari Papua Barat 98314, Indonesia;

(1) GAFM https://orcid.org/0000-0002-9934-158X, (1) KK https://orcid.org/0000-0003-3504-0582,

(1) IM https://orcid.org/0000-0002-1475-9224, (1) MM https://orcid.org/0000-0002-0668-5317,

(1) YA https://orcid.org/0000-0002-7691-7961, (1) HM https://orcid.org/0000-0002-7598-6869,

(D) KEP https://orcid.org/0000-0003-2758-4395, (1) SR https://orcid.org/0000-0001-5985-7437,

(1) AK https://orcid.org/0000-0003-1327-2884, (1) SB https://orcid.org/0000-0003-2730-5798,

(1) NN-A https://orcid.org/0000-0003-4051-8288

N. M. H. Benu, J. Tambing, R. Kuswandi, L. Khayati, K. Lekitoo, Balai Penelitian dan Pengembangan Lingkungan Hidup dan Kehutanan (BP2LHK) Manokwari Papua Barat 98314, Indonesia;

(1) NMHB https://orcid.org/0000-0003-3504-126X, (1) JT https://orcid.org/0000-0003-4679-0274,

(D) RK https://orcid.org/0000-0002-2713-5656, (i) LK https://orcid.org/0000-0002-0174-3987,

(1) KL https://orcid.org/0000-0002-9117-2769

*Corresponding author

\section{Introduction}

Tropical rain forests harbor high biodiversity along with abiotic factors. The high variation in vegetation creates a place of wildlife habitation (Bonnell et al., 2011; Rosin, 2014; Finnegan et al., 2019). Also, forests provide ecosystem functions, including nutrient cycles (Vitoussek \& Sanford, 1986; Gleason et al., 2010; Johnson \& Turner, 2019), hydrological function (Edwards et al., 2014), and protection for soil and water. Consequently, tropical forests are imperative to preserve the integrity of naturally formed ecosystems (Luize et al., 2018). Moreover, current research showed that the role of tropical forests has a relationship with global warming (Taylor et al., 2017). Degradation and deforestation are driving factors of climate change as atmospheric composition indicate an increase in the number of greenhouse gases (Aguilos et al., 2018; Fleischer et al., 2019). The trees in tropical rain forests play an important role in ecological function such as watershed regulation, support biodiversity of vegetation and wildlife (Gaveau et al., 2013; Naniwadekar et al., 2015; Ueda et al., 2017; Riggs et al., 2020). Therefore, the understanding of forest conditions is vital to manage sustainability with declining vegetation over time. This instigates a change in ecosystems previously stable or at equilibrium levels in the woods (Sist et al., 2015; Levis et al., 2017).

The forests of Papua presently contain natural tropical vegetation (Hughes et al., 2015; Kuswandi et al., 2015; Grussu et al., 2016; Cámara-Leret et al., 2020; Murdjoko et al., 2020). Although, some places have experienced changes in ecological function (Murdjoko, 2013; Kuswandi et al., 2015; Laurance, 2015; Murdjoko et al., 2017). Furthermore, the potential change in this region is possibly due to an impact from the pressure of development during regional expansion in Papua districts (Fatem et al., 2018; Indrawan et al., 2019; Tawer et al., 2020). This condition is a dilemma in sustainable forest management, on one hand, there is a high economic demand for timber or non-timber forest products and more threatening is the policy pressure to convert forest areas for other purposes. However, the woods need to be properly controlled. Therefore, proper knowledge of sustainable management particularly development planning is essential for various parties. This includes policymakers, the public or private sector, researchers, and others (Mansourian, 2017).

The benefit of these regions is understood from the view of forests as vegetation areas and also assessed in the comprehensive form with as much 
detail as possible. Moreover, among these tropical forests, habitats in the form of ecosystems, animals, social culture, and environmental services are potentially provided by the existence of a stable condition within tropical forests (Liu \& Slik, 2014). Therefore, it is imperative to study these regions particularly vegetation, including the distribution, population, species diversity, and others. This research was intended to study the diversity of trees and analyze the individual distribution, and conservation status of Nikiwar Forests, Teluk Wondama District as a natural tropical forest.

\section{Methods}

\section{Study area}

This research was conducted in Nikiwar District, Teluk Wondama Regency at four different locations, Idoor, Karst, Persemaian, and Torembi. The geographical coordinates are: Idoor at $2^{\circ} 27^{\prime} 54.32 " S$; $134^{\circ} 6^{\prime} 21.02 " \mathrm{E}$, Karst at $2^{\circ} 29^{\prime} 6.26^{\prime \prime}$; $134^{\circ} 7^{\prime} 16.40^{\prime \prime} \mathrm{E}$, Persemaian in $2^{\circ} 25^{\prime} 49.28^{\prime \prime} \mathrm{S} ; 134^{\circ} 7^{\prime} 54.48^{\prime \prime} \mathrm{E}$, and Torembi at $2^{\circ} 23^{\prime} 27.09 " S ; 134^{\circ} 7^{\prime} 47.27^{\prime \prime E}$. Furthermore, the forest is a primary type divided into four groups characterized by ecological conditions especially edaphic and topographic factors. Furthermore, Torembi and Persemaian represent the eastern part while Idoor and Karst represent the western region.

\section{Data collection}

The species are divided into four parts, seedlings, saplings, poles, and trees. Subsequently, seedlings are marked to have a height of less than $1.5 \mathrm{~m}$. Also, saplings are marked with a height of more than $1.5 \mathrm{~m}$ and a diameter of less than $10 \mathrm{~cm}$. The pole has a diameter between $10 \mathrm{~cm}$ and $20 \mathrm{~cm}$ and the tree has a diameter greater than $20 \mathrm{~cm}$.

Also, data collected from each plot are individual species and each one is identified according to the scientific name. Two vegetation experts from the herbarium technician identified tree species. The unidentified species were set as a voucher and sent to Herbarium Papuense, Balai Penelitian dan Pengembangan Lingkungan Hidup, and Kehutanan (BP2LHK) Manokwari and Herbarium Manokwariense (MAN) Pusat Penelitian Keanekaragaman Hayati (PPKH) Universitas Papua. Subsequently, the number of each species in the plot was recorded. Also, diameter at breast height $(1.3 \mathrm{~m})$ or $20 \mathrm{~cm}$ above the buttress was calculated for poles and trees, excluding seedling and sapling phases.
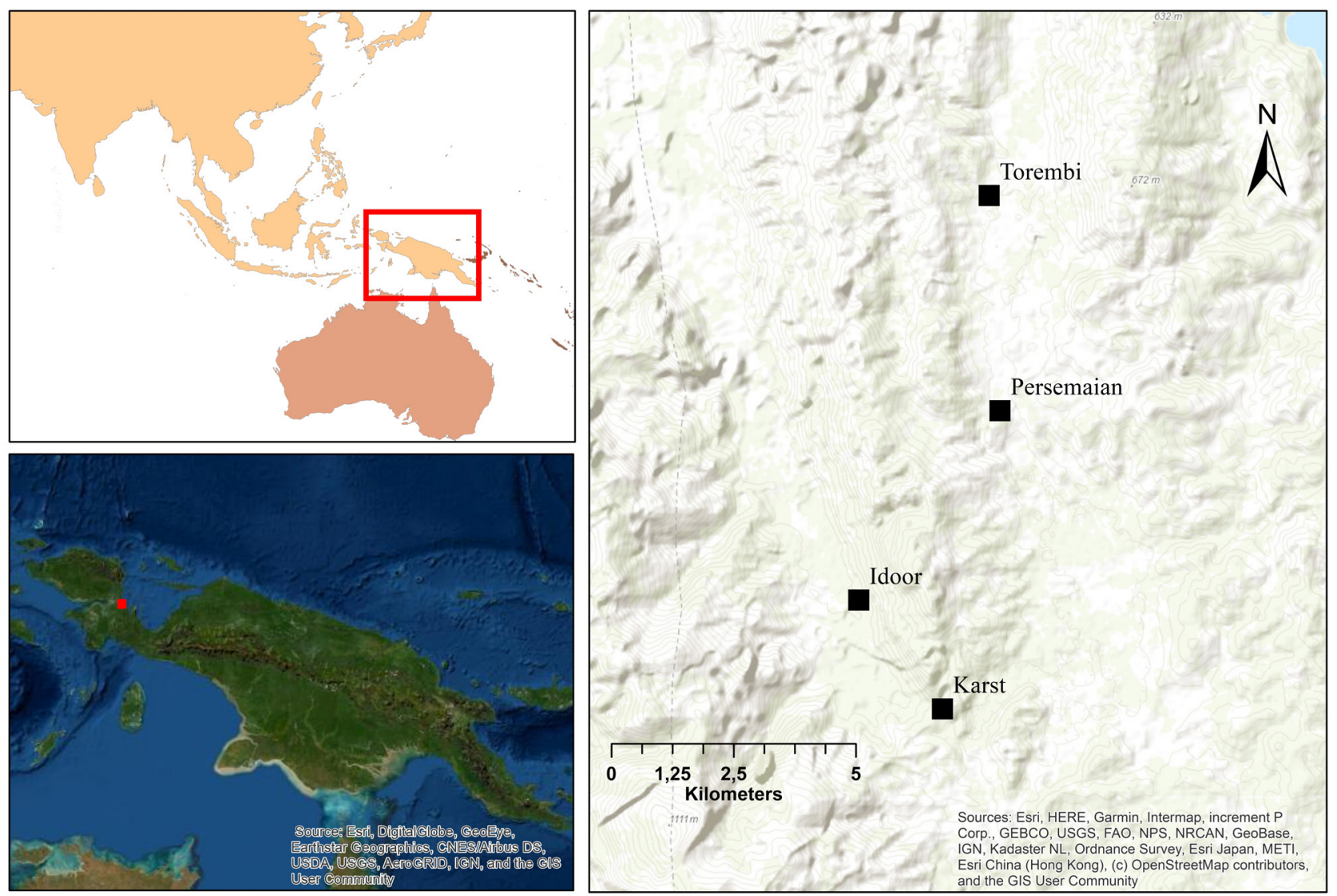

Fig. 1. Location of research (black boxes). The location is administratively part of Nikiwar District, Teluk Wondama Regency, West Papua, Indonesia 
The plot used for this study consisted of four sizes, $2 \mathrm{~m} \times 2 \mathrm{~m}$ for seedlings; $5 \mathrm{~m} \times 5 \mathrm{~m}$ for saplings; $10 \mathrm{~m} \times 10 \mathrm{~m}$ for the pole, and $20 \mathrm{~m} \times 20 \mathrm{~m}$ for trees. A total of 23 plots were put in place with 7 plots in Idoor, 4 plots in Karst, 7 plots in the Persemaian, and 5 plots in Torembi. Also, plots at each location were randomly arranged on transects where the distances between plots at least $50 \mathrm{~m}$ were.

\section{Data analysis}

The basal area (BA) is calculated by considering the diameter of the tree species as follows, $B A_{i}=\sum D_{i}^{2} \times 0.7854$, where $B A_{i}=$ basal area $\left(\mathrm{m}^{2}\right)$ of tree species i, $D_{i}=$ diameter $(\mathrm{m})$ of tree species $\mathrm{i}$, and $0.7854=\pi / 4$. Then, to evaluate $B A$ per hectare, the tree species are divided based on using the plot area $\left(\mathrm{m}^{2} \mathrm{ha}^{-1}\right)$ as density. However, $B A$ for each tree species describes the extent of dominance at the site. Density is used to ascertain the number of tree species per hectare (trees $\mathrm{ha}^{-1}$ ). Frequency shows the distribution of each tree species. Next, the number of plots with the tree species i, is divided by the total number of sample plots. Therefore, frequency is calculated using the equation $\mathrm{Fr}_{i}=\frac{n_{i}}{N}$ where $F r_{i}=$ Frequency of tree species i, $n_{i}=$ number of plots where tree species $\mathrm{i}$ was located and $=$ total number of sample plots. Importance Value Index (IVI) determines the distribution of each tree species in terms of dominance (Curtis \& McIntosh, 1950; Nirmal Kumar et al., 2011). This index is calculated by adding the relatives of frequency, density, and dominance as $I V I_{i}=R F r_{i}+R D e_{i}+R D o_{i}$ where $I V I_{i}=$ importance value index of tree species $i, R F r_{i}=$ relative frequency of tree species $i, R D e_{i}=$ relative density of tree species $i$, and $R D o_{i}=$ relative dominance of tree species $i$. Diversity Index - the diversity between locations was tested using a diversity index (Shannon, 1948; Spellerberg \& Fedor, 2003). Also, the ShannonWeiner diversity index was chosen as a parameter to describe the distribution of each species in terms of the number of individuals by calculating the evenness (E) (Pielou, 1966). A diversity index is calculated using the equation, $H^{\prime}=-\sum p_{i} \ln \left(p_{i}\right)$ where $H^{\prime}=$ Shannon-Weiner diversity index and $p_{i}=$ number of samples with tree species $i$. The evenness is measured by the equation $E=\frac{H^{\prime}}{\ln (S)}$ where $S$ is the number of species for each location.

\section{Statistical analysis}

Cluster dendrogram and the analysis of variance (ANOVA) were applied to investigate the statistical variation between the four locations. The computation was performed with R-3.6.3 for Windows ( $R$ Development Core Team 2014) and vegan package (Oksanen et al., 2019).

\section{Results}

\section{Diversity and taxonomic composition}

This research generated 76 tree species from 35 identified families. Subsequently, the dendrogram was grouped into three, including Idoor and Torembi (combined), Persemaian, and Karst (Fig. 4). Also, the dominant families varied among the four forests where Sapindaceae, Myristicaceae, Meliaceae, Euphorbiaceae, and Ebenaceae in Indoor; Euphorbiaceae, Ebenaceae, Leguminosae, Sapindaceae, and Apocynaceae in Karst; Dipterocarpaceae, Phyllanthaceae, Leguminosae, Myristicaceae, and Myrtaceae in Persemaian; Myristicaceae, Sapindaceae, Lauraceae, Dipterocarpaceae, and Lamiaceaein Torembi (Fig. 2). Under the species level of species within the four locations, the species distribution was uniformly distributed based on Evenness (E) (Fig. 3 B). However, the number of individuals showed more variation with Torembi, followed by Persemaian, Idoor, and Karst. Diversity Index $\left(\mathrm{H}^{\prime}\right)$ differed significantly in species distribution $(P=0.002)$, while the evenness index did not show any significant difference $(P=0.302)$. Persemaian was observed with the lowest diversity compared to the other three locations. Furthermore, Idoor and Karst indicated the highest species diversity, while Torembi maintained a similar situation as all locations (Fig. 3 A and Fig. 5).

Species at the seedling level in Idoor were dominated by Myristica sp, Pometia sp, Aglaia sp, and Diospyros sp, while Karst was mainly presented by Diospyros sp, Myristica sp, Palaquium amboinense Burck, and Spathiostemon sp. Furthermore, Vatica rassak Blume, Myristica sp, Baccaurea sp, and Neonauclea sp, were present in Persemaian, followed by Myristica sp, Palaquium amboinense Burck, Pometia sp, and Canarium sp in Torembi. At

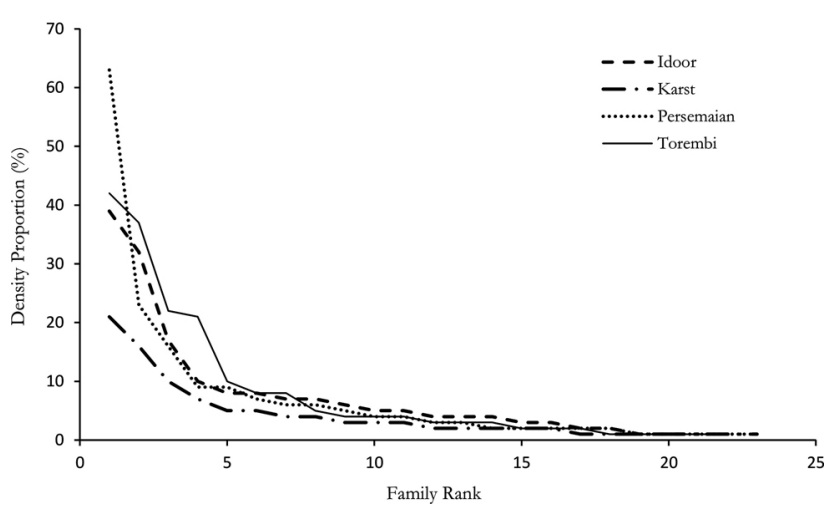

Fig. 2. Composition of family rank of tree in four locations 

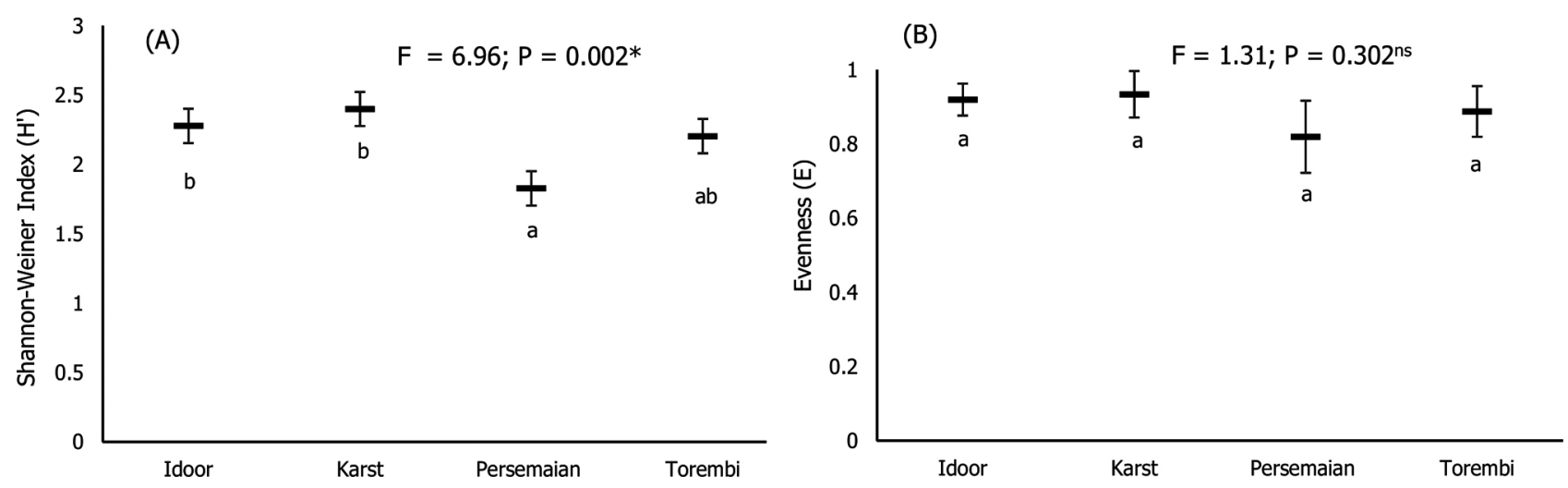

Fig. 3. The diversity index $\left(\mathrm{H}^{\prime}\right)$ in A and Evenness (E) in B where $\mathrm{F}$ is analysis of variance (ANOVA), the asterisk $\left({ }^{*}\right)$ is the significance of $F$ values from the ANOVA indicated that $\mathrm{P}<0.05$, ns is no significance of $\mathrm{F}$ values from the ANOVA indicated that $\mathrm{P}>0.05$, and the different lowercase letters show the significant differences

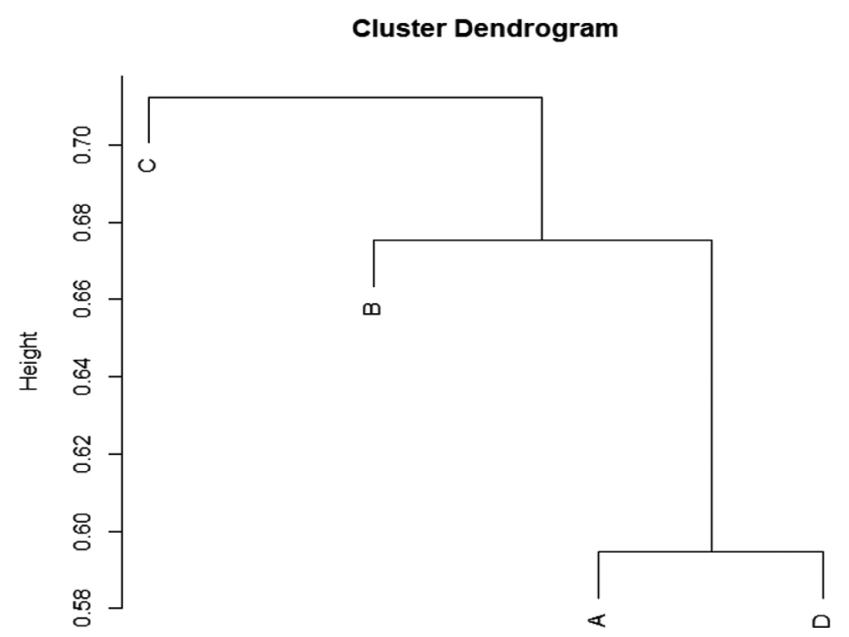

Fig. 4. Cluster dendrogram of the four locations which are represented by uppercase, viz., A - Idoor, B - Karst, C - Persemaian, D - Torembi

this seedling level, three species termed Myristica sp, Pometia sp, and Palaquium amboinense Burck existed in more than two places (Fig. 6). Specifically, Myristica sp showed dominance in these four locations with a high importance value index. This indicates the species with a high capacity to regenerate, particularly during the fertilization and germination processes.

At the sapling level in Idoor region, Myristica sp, Aglaia cucullata (Roxb.) Pellegr., Baccaurea sp, and Ganophyllum falcatum Blume were observed, followed by Chisocheton macrophyllus King, Diospyros sp, Spathiostemon javensis Blume, and Buchanania spume in Karst. Furthermore, several species of Baccaurea sp, Vatica rassak Blume, Fagraea racemosa Jack, and Syzygium sp were discovered in Persemaian, while in Torembi, the dominant species involved Chisocheton macrophyllus King, Myristica sp, Syzygium sp, and Alstonia scholaris (L.) R. Br. (Fig. 7). Also, 2 species, termed Myristica sp and Syzygium sp, occurred in more than one location. These conditions indicate the ability to develop from seedling to sapling level as both varieties were more effective, particularly Myristica sp.

Various groups at the pole level differ from species dominance at seedling and sapling levels. This is observed in Idoor, and is dominated by Pimelodendron amboinicum Hassk., Pometia coriacea Radlk., Macaranga tanarius (L.) Müll.Arg. and Horsfieldia sylvestris Warb. Also, in Karst, abundant species, including Pimelodendron amboinicum Hassk., Intsia palembanica Miq., Pometia acuminata Radlk. and Ficus septica Burm.f. were present. In Persemaian, the majority of individuals at the pole level were Vatica rassak Blume, Pimelodendron amboinicum Hassk., Myristica fatua Houtt. and Syzygium sp, while for Torembi, the number of groups of Vatica rassak Blume, Pimelodendron amboinicum Hassk., Teijsmanniodendron sp, and Myristica fatua Houtt occurred in large quantity at the pole (Fig. 8). Of all the species present at the pole level, three varieties, termed Pimelodendron amboinicum Hassk., Vatica rassak Blume, and Myristica fatua Houtt were extensive, especially $P$. amboinicum. At the tree level, Tetrameles nudiflora R. Br., Campnosperma brevipetiolatum Volkens, Pometia coriacea Radlk., and Pometia acuminata Radlk. developed in large numbers within the Idoor region, while Pometia acuminata Radlk., Intsia palembanica Miq., Ficus pungens Reinw. ex Blume and Pimelodendron amboinicum Hassk occurred in Karst, where more existed as dominant species. Furthermore, Persemaian was dominated by Intsia palembanica Miq., Vatica rassak Blume, Myristica fatua Houtt., and Hopea papuana Diels, while Vatica rassak Blume, Teijsmanniodendron hollrungii (Warb.) Kosterm., Artocarpus altilis (Parkinson ex F.A. Zorn) Fosberg, and Pometia coriacea Radlk occurred abundantly in Torembi (Fig. 9). Among all species, Pometia coriacea Radlk., Pometia acuminata Radlk., Intsia palembanica Miq., and Vatica rassak Blume were individuals cultivated and controlled in more than one location, specifically, I. palembanica is known to dominate the tree level. 


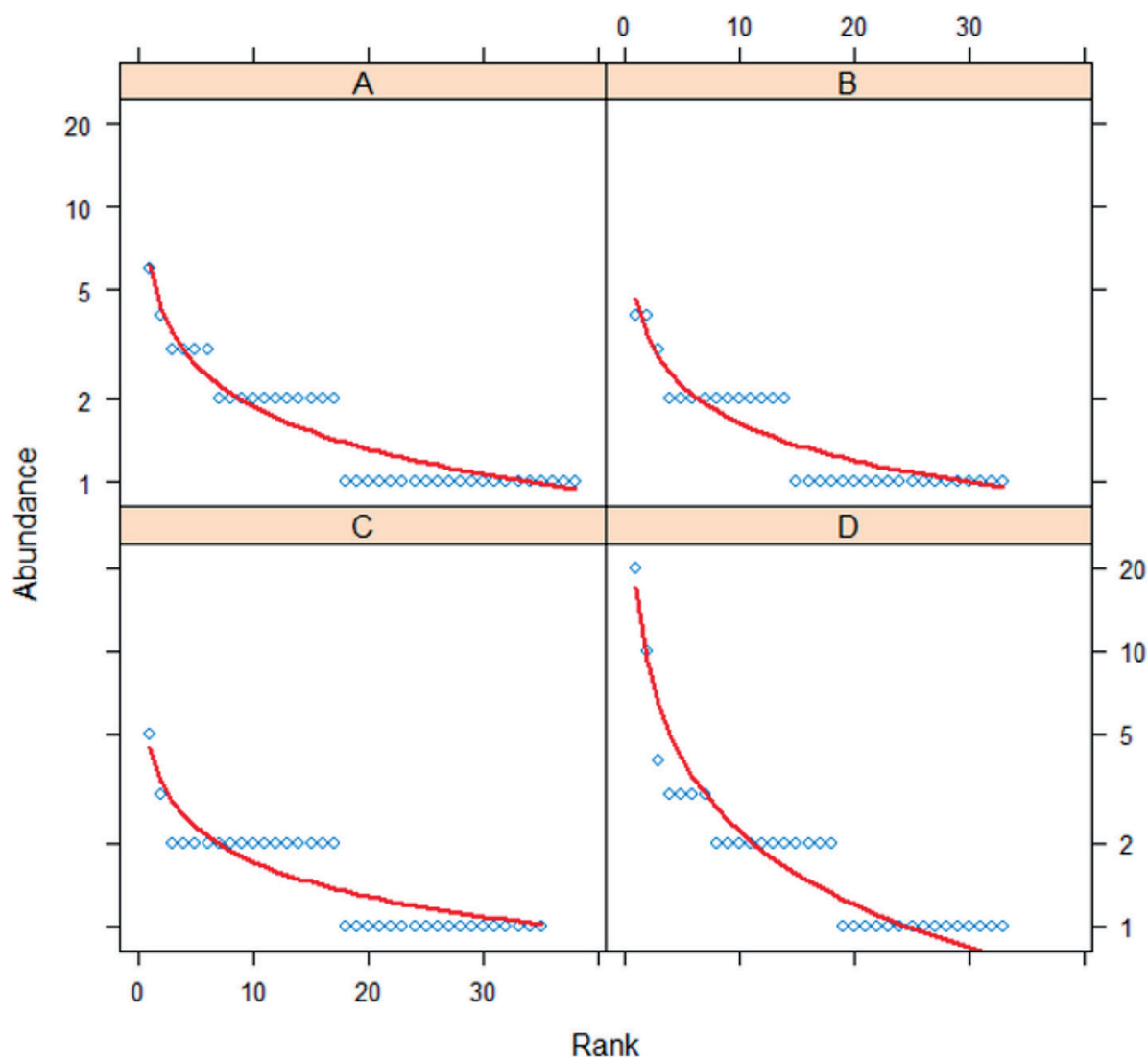

Fig. 5. Proportion of individual abundance based on the tree species in four locations. A - Idoor, B - Karst, C - Persemaian, D - Torembi

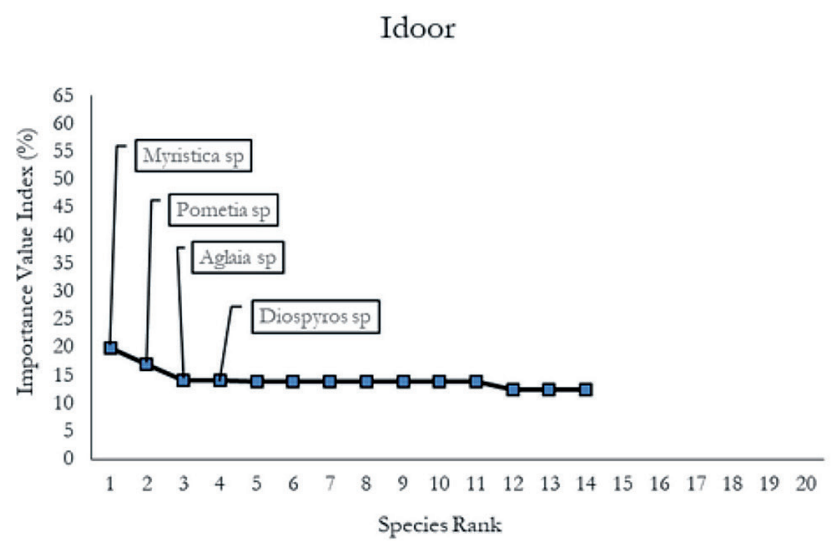

Persemaian

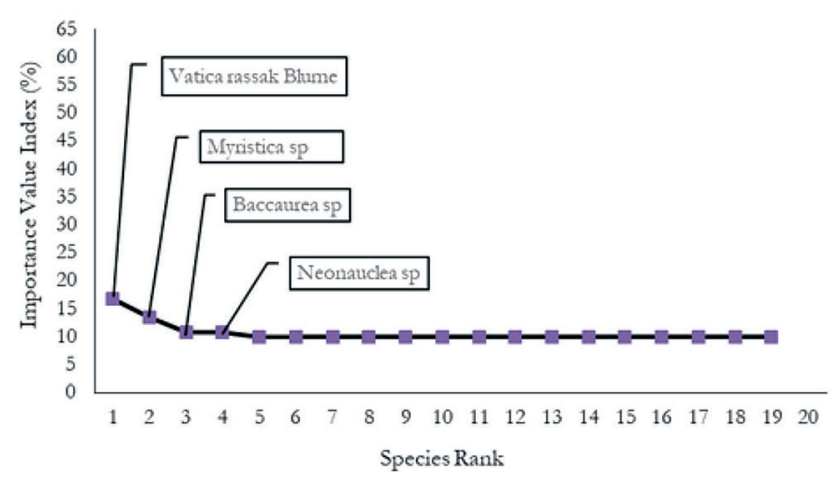

Karst

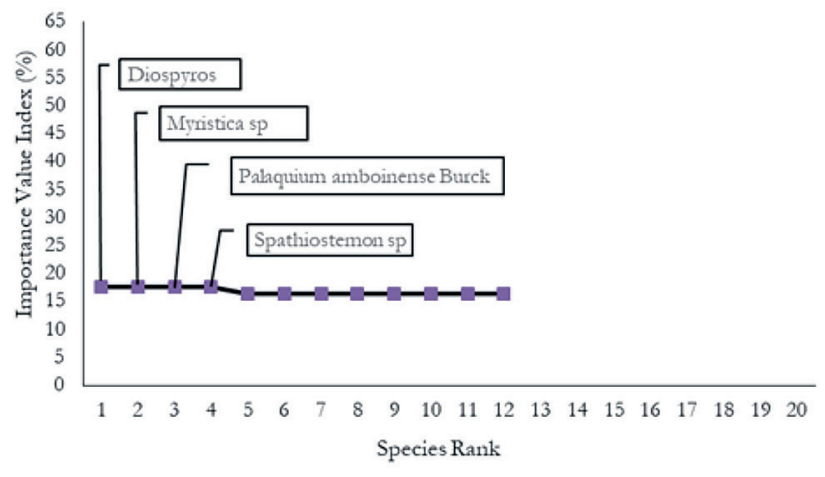

Torembi

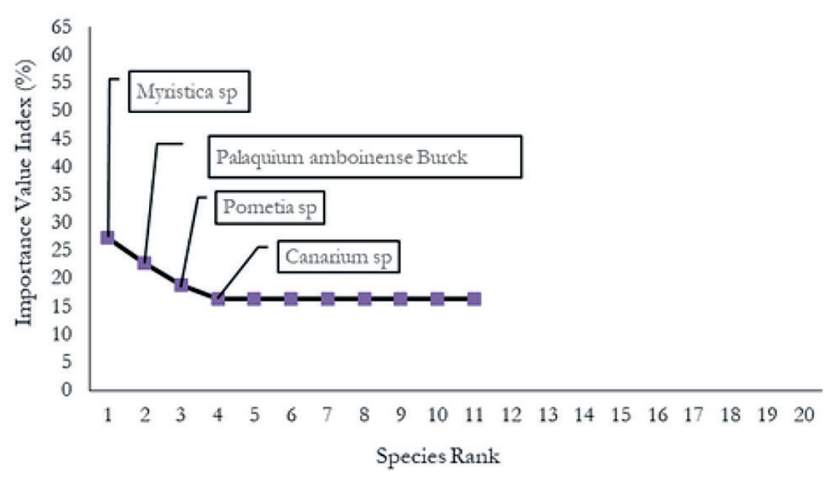

Fig. 6. Importance Value Index (IVI) for seedlings and the label show the four most dominant species in each location 
Idoor

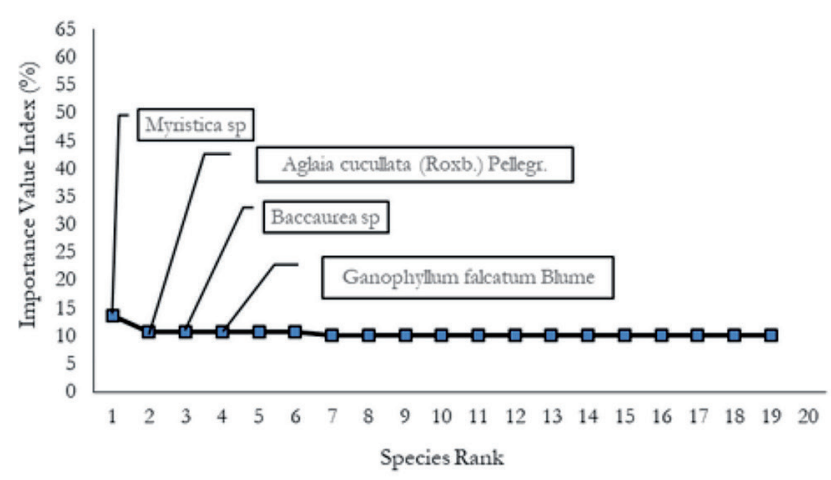

Persemaian

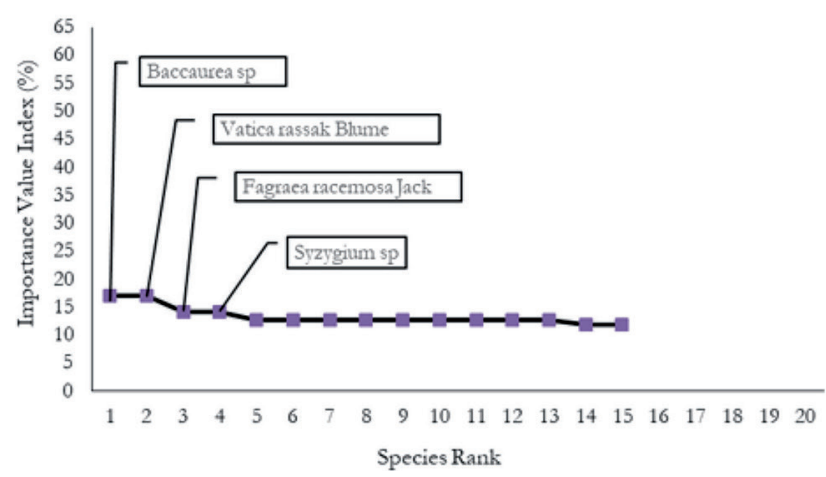

Karst

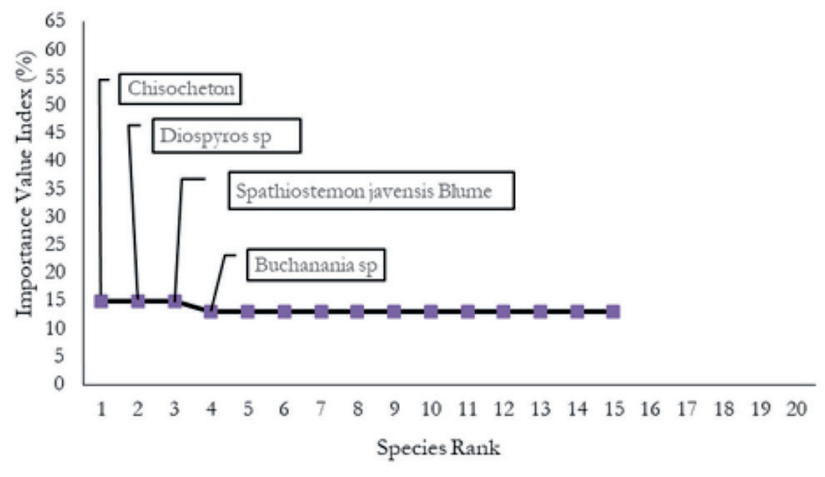

Torembi

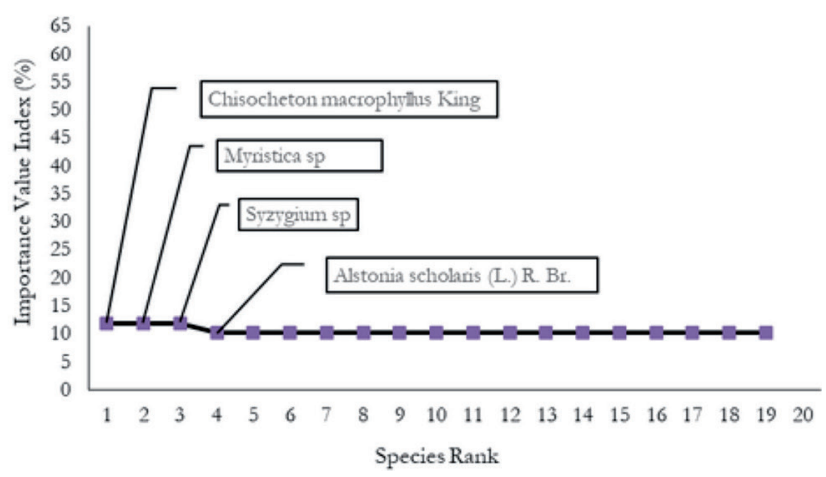

Fig. 7. Importance Value Index (IVI) for saplings and the label show the four most dominant species in each location

Idoor
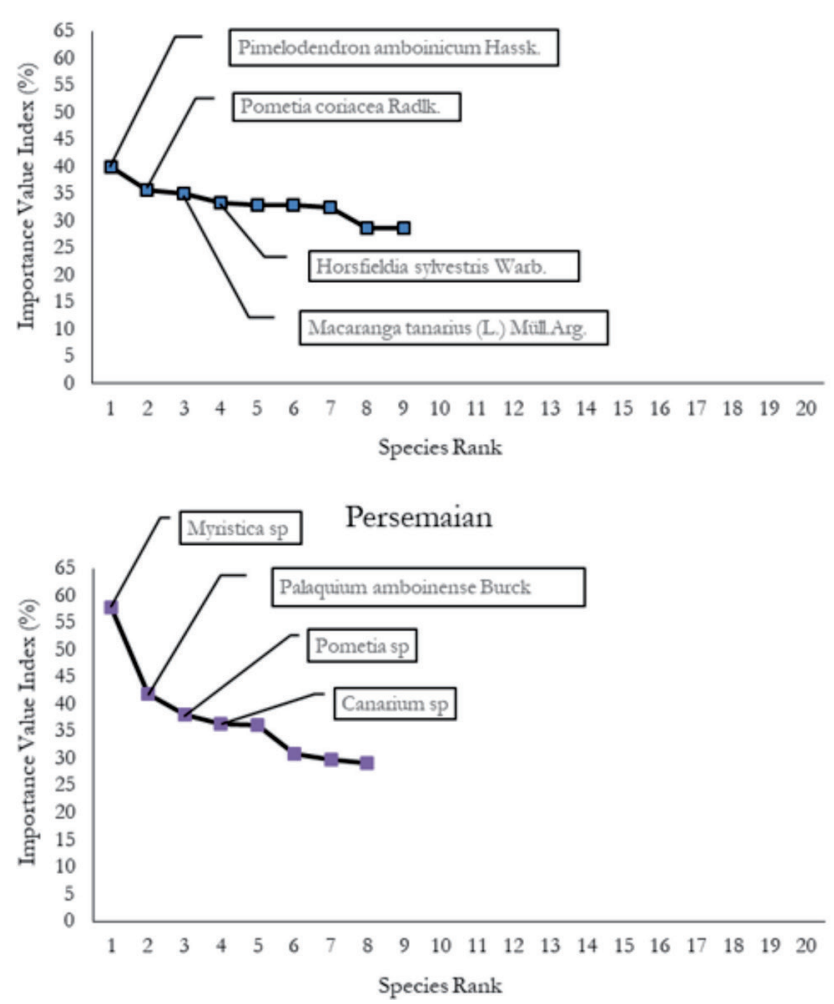

Karst

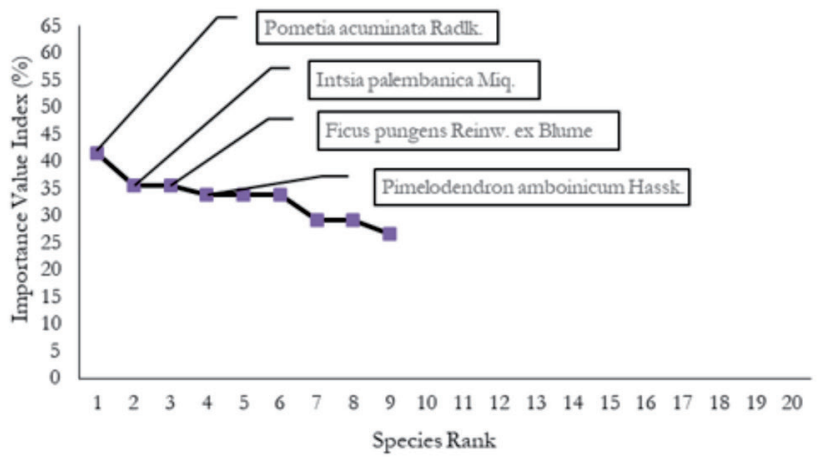

Torembi

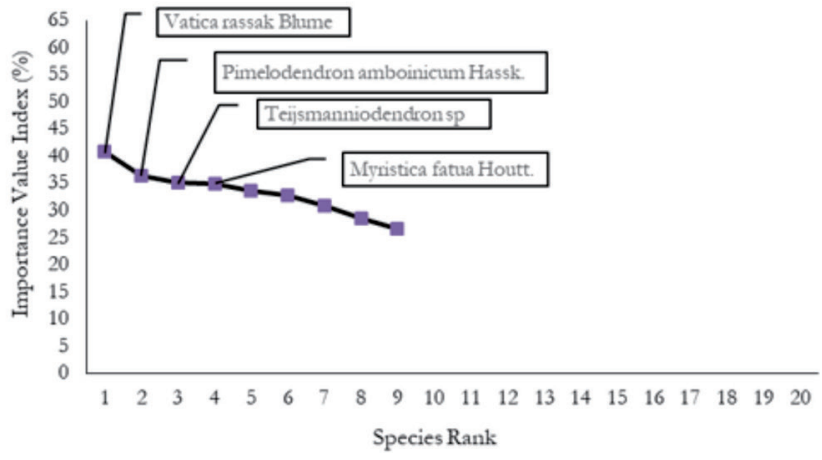

Fig. 8. Importance Value Index (IVI) for poles and the label show the four most dominant species in each location 

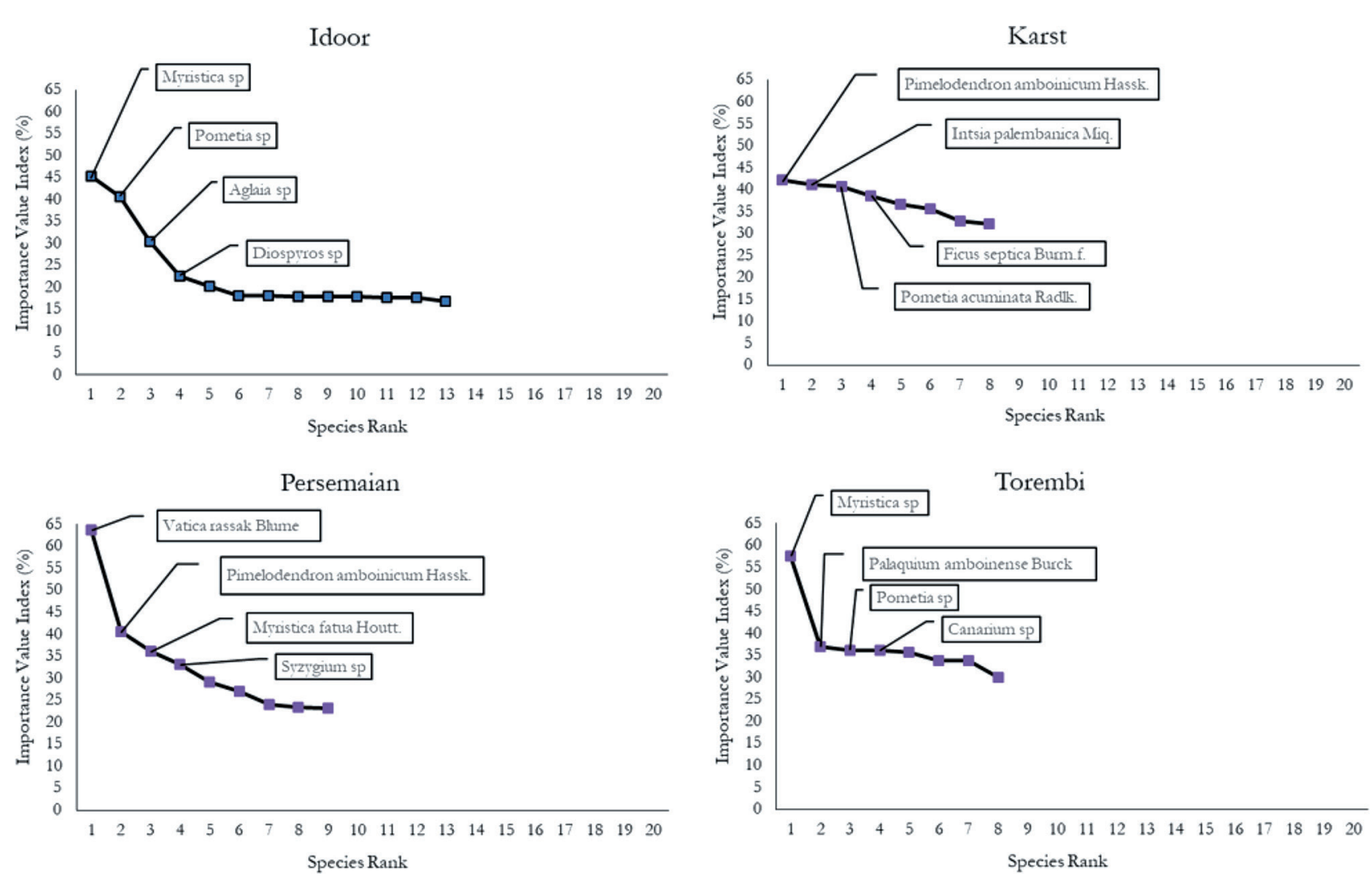

Fig. 9. Importance Value Index (IVI) for trees and the labels show the four most dominant species in each location

\section{Distribution of individual tree based on the diameter}

Wood forest products are described in the form of diameter distribution in each location, where the greater diameter is known to increase the potentials for these products. At these locations, individual trees spread out at various diameters ranging from insignificant values to approximately $200 \mathrm{~cm}$. This generates a distribution pattern in tropical forests where individuals with lesser diameter are more extensive compared to the number of individuals with a larger diameter.

Based on the results of the non-linear regression analysis, the equation formed was specified as $\mathrm{y}=2.4422 \mathrm{x}^{-0.23}$ with $\mathrm{R}^{2}=0.27$ (Fig. 10). This showed the larger diameter instigates lesser individuals in the forest area. Furthermore, the diameter size drastically decreases, commencing from $40 \mathrm{~cm}$, while the number of individual diameters below 25 $\mathrm{cm}$ demonstrated higher values. Meanwhile, individuals with diameters above $100 \mathrm{~cm}$ existed in Idoor and Persemaian.

\section{Conservation status of tree species}

In the four forest types, certain species develop from a variety. Table 1 shows the results of conservation status analysis based on the website www. iucnredlist.org, as 76 tree species (Table 1). Table 2 highlights four significant statuses, termed critically endangered (CR) of 2 species, vulnerable (VU) of 6 species, least concern (LC) of 28 species, and data deficient (DD) species. Of all these varieties, CR and VU specifically indicated a status population decline in forest areas caused by the conversion of the
Idoor

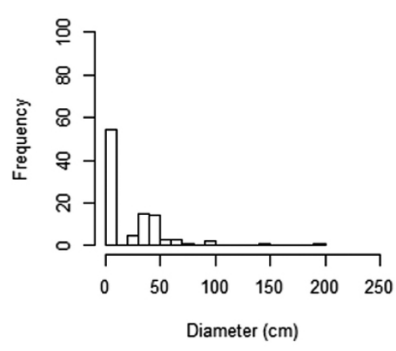

Persemaian

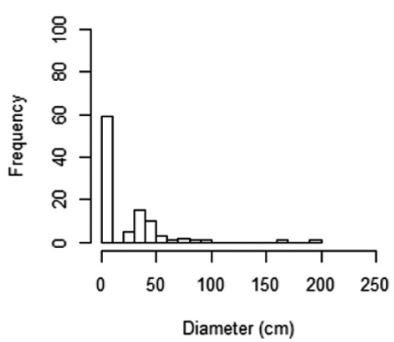

Karst

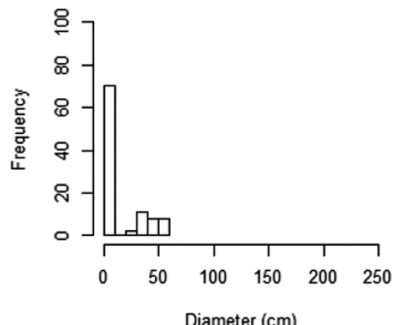

Torembi

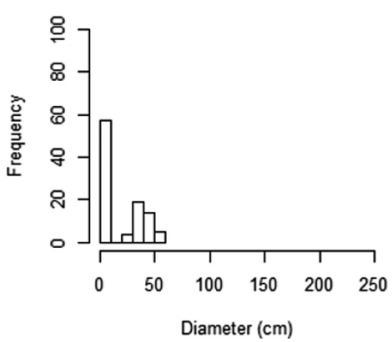

Fig. 10. The proportion of individuals based on diameter class in each location 
Table 1. Conservation status of tree species in the four locations

\begin{tabular}{|c|c|c|c|}
\hline Species & Family & Conservation status & Population status \\
\hline Memecylon sp & Melastomataceae & Critically Endangered (CR) & Decreasing \\
\hline Syzygium sp & Myrtaceae & Critically Endangered (CR) & \\
\hline Crudia sp & Leguminosae & Vulnerable (VU) & \\
\hline Garcinia sp & Clusiaceae & Vulnerable (VU) & Decreasing \\
\hline Intsia bijuga (Colebr.) Kuntze & Leguminosae & Vulnerable (VU) & \\
\hline Litsea sp & Lauraceae & Vulnerable (VU) & \\
\hline Pisonia sp & Nyctaginaceae & Vulnerable (VU) & Stable \\
\hline Pterygota sp & Malvaceae & Vulnerable (VU) & \\
\hline Aglaia sapindina (F.Muell.) Harms & Meliaceae & Least Concern (LC) & \\
\hline Alstonia scholaris (L.) R. Br. & Apocynaceae & Least Concern (LC) & \\
\hline Breonia chinensis (Lam.) Capuron & Rubiaceae & Least Concern (LC) & \\
\hline Baccaurea sp & Phyllanthaceae & Least Concern (LC) & \\
\hline Bischofia javanica Blume & Phyllanthaceae & Least Concern (LC) & Stable \\
\hline Calophyllum inophyllum L. & Clusiaceae & Least Concern (LC) & Stable \\
\hline Cerbera floribunda K.Schum. & Apocynaceae & Least Concern (LC) & Stable \\
\hline Cynometra ramiflora $\mathrm{L}$. & Leguminosae & Least Concern (LC) & \\
\hline Cynometra sp & Leguminosae & Least Concern (LC) & \\
\hline Nageia wallichiana (C.Presl) Kuntze & Podocarpaceae & Least Concern (LC) & Decreasing \\
\hline Diospyros sp & Ebenaceae & Least Concern (LC) & \\
\hline Ficus septica Burm.f. & Moraceae & Least Concern (LC) & Stable \\
\hline Ganophyllum falcatum Blume & Sapindaceae & Least Concern (LC) & Stable \\
\hline Gnetum gnemon L. & Gnetaceae & Least Concern (LC) & \\
\hline Horsfieldia irya (Gaertn.) Warb. & Myristicaceae & Least Concern (LC) & \\
\hline Horsfieldia sylvestris Warb. & Myristicaceae & Least Concern (LC) & \\
\hline Macaranga tanarius (L.) Müll.Arg. & Euphorbiaceae & Least Concern (LC) & Stable \\
\hline Medusanthera laxiflora (Miers) R.A.Howard & Stemonuraceae & Least Concern (LC) & Decreasing \\
\hline Melicope elleryana (F. Muell.) T.G. Hartley & Rutaceae & Least Concern (LC) & Stable \\
\hline Spathiostemon javensis Blume & Euphorbiaceae & Least Concern (LC) & Stable \\
\hline Spathiostemon sp & Euphorbiaceae & Least Concern (LC) & \\
\hline Prunus sp & Rosaceae & Least Concern (LC) & Stable \\
\hline Tabernaemontana aurantiaca Gaudich. & Apocynaceae & Least Concern (LC) & Stable \\
\hline Tetrameles nudiflora $\mathrm{R} . \mathrm{Br}$. & Tetramelaceae & Least Concern (LC) & Stable \\
\hline Teijsmanniodendron hollrungii (Warb.) Kosterm. & Lamiaceae & Least Concern (LC) & Stable \\
\hline Teijsmanniodendron sp & Lamiaceae & Least Concern (LC) & Stable \\
\hline Vatica rassak Blume & Dipterocarpaceae & Least Concern (LC) & Decreasing \\
\hline Vitex quinata (Lour.) F.N.Williams & Lamiaceae & Least Concern (LC) & \\
\hline Aglaia cucullata (Roxb.) Pellegr. & Meliaceae & Data Deficient (DD) & Decreasing \\
\hline Aglaia sp & Meliaceae & Data Deficient (DD) & Decreasing \\
\hline
\end{tabular}

Table 2. The number of species with conservation status in the four location

\begin{tabular}{lcccc}
\hline Locations & \multicolumn{4}{c}{ Conservation status } \\
\cline { 2 - 5 } & $\begin{array}{c}\text { Critically } \\
\text { Endangered } \\
(\mathrm{CR})\end{array}$ & $\begin{array}{c}\text { Vulnerable } \\
\text { (VU) }\end{array}$ & $\begin{array}{c}\text { Least Concern } \\
\text { (LC) }\end{array}$ & $\begin{array}{c}\text { Data } \\
\text { Deficient } \\
\text { (DD) }\end{array}$ \\
\hline Idoor & 1 & 4 & 13 & 1 \\
Karst & 2 & 0 & 12 & 0 \\
Persemaian & 1 & 3 & 11 & 1 \\
Torembi & 1 & 1 & 11 & 0 \\
\hline
\end{tabular}

landscape to other purposes without any provision of ex-situ conservation programs. Therefore, 8 species, particularly the types with decreasing population status, including Memecylon sp and Garcinia sp, were assumed to demand more attention in the regeneration process, which is achieved by human intervention, e.g. planting. Specifically, in Papua, the species Intsia bijuga (Colebr.) Kuntze with a commercial value and construction material input requires a program to support the regeneration process.

Based on total species distribution, the groups with CR status existed in all the locations, while VU occurred only in Karst. Also, LC species were scattered across the entire region. This situation showed critical interventions involving species regeneration, especially CR and VU are necessary. Also, the research revealed the four locations are places or habitats of these species. Therefore, preserving natural areas from forests appears as a suitable initiative towards providing opportunities and growth for these species. Further studies on regeneration, spatial 
distribution, and the distinct characteristics of these species are paramount to support conservation programs, particularly species with critically endangered (CR) and vulnerable (VU) status.

\section{Discussion}

The species indigenous to each location constitute the communities. Based on the vegetation analyses of the four locations, a diverse natural forest with evenly distributed breeds was formed. This condition is typical of primary tropical forests in Papua. A wide variety of vegetation including lianas, rattan, herbs, forest floor coverings, epiphytes, and others are native to these zones (Murdjoko et al., 2016a). However, this study is limited to the seedlings, saplings, poles, and trees located in Idoor, Persemaian, Karst, and Torembi regions.

Generally, vegetation in the under-story layer of dense forests is exposed to less sunlight, high humidity, and lower temperatures than other flora (Nopiansyah et al., 2017; de Winter et al., 2018). Myristica sp was discovered to dominate this stratum. Therefore, the species are speculated to be tolerant of these conditions, particularly shade. Meanwhile, poles and trees constitute the upper-story. At this level, $V$. rassak is prevalent because the plant grows well under exposure to direct sunlight, low humidity as well as high temperature (Corrià-Ainslie et al., 2015).

This species is present at the highest stratum and also in the undergrowth. Meanwhile, some plants, including, I. palembanica do not have this ability. Therefore, such plants, especially those common to the upper canopy, bear flowers and fruit, but are unable to support regeneration in lower altitudes (Murdjoko et al., 2016b). This may be a limiting factor concerning species-specific predation. Also, the probability of a seed to germinate at the forest floor influences individual initiation. Furthermore, seedlings capable of thriving in the presence of little or no sunlight have higher chances of survival (Gudiel et al., 2016; Fatem et al., 2020).

This increases the competition between plants at the understory as there are numerous shade-tolerant plants in a typical tropical woodland (Do et al., 2019). Besides, some individuals of flora are allelopathic and are capable of releasing biochemical agents to impede growth or even kill these contenders ( $\mathrm{Fa}$ celli \& Pickett, 1991; Ladwig et al., 2012). Also, the presence of species-specific herbivorous predators may influence continuity in a bio-diverse habitat (Balandier et al., 2006).

\section{Recommendations for management based on sustainable principles}

Tree diversity and ecosystem formation are common characteristics of a mixed natural forest. Hence, there is a potential for bio-diversified vegetation. Also, these species possess economic benefits (Gaveau et al., 2014; Pryde et al., 2015; Colín-Urieta et al., 2018). Furthermore, the ecological use of these locations ought to be considered. For instance, Karst is a highland zone and may serve as a rainwater catchment area when conserved. Meanwhile, Idoor, Persemaian, and Torembi constitute the lowlands and are readily accessible sources of timber as well as other forest products.

However, Critically Endangered (CR) and Vulnerable (VU) species must be properly managed to avoid a population decline. Therefore, inventory is necessary to ascertain the degree of diversity. Also, in-situ and ex-situ programs may be integrated to increase effectiveness (Todou et al., 2014; Ren et al., 2019). For instance, in the Persemaian region, this may be achieved by the creation of a buffer location where fauna of economic and ecological importance are made available and those of CR and VU status remain preserved. Subsequently, the success of this technique is evaluated through continual research. Furthermore, the germination and growth supporting capacity of habitats are studied to provide practical solutions for nursery development and acceleration of regrowth in slowly regenerating plants, including I. palembanica.

\section{Acknowledgments}

The authors are grateful to Kopermas Kami Nassey for financial support towards the Biodiversity and Conservation Assessment in Nikiwar Forest, Teluk Wondama Regency, West Papua. The authors are also thankful to Jonathan Mozes Nassey, indigenes of Nikiwar district, Bertha Mangallo, Ihwan Tjolli, Hubertus Matanubun, Maria J. Sadsoeitoeboen, Jacob Manusawai, Daniel Leonard Haumahu for field assistance, permit, and administration during the research. We also thank the anonymous reviewers for improving this article.

\section{References}

Aguilos M, Hérault B, Burban B, Wagner F \& Bonal D (2018) What drives long-term variations in carbon flux and balance in a tropical rainforest in French Guiana? Agricultural and Forest Meteorology 253-254: 114-123. doi:10.1016/j.agrformet.2018.02.009. 
Balandier P, Collet C, Miller JH, Reynolds PE \& Zedaker SM (2006) Designing forest vegetation management strategies based on the mechanisms and dynamics of crop tree competition by neighbouring vegetation. Forestry 79: 3-27. doi:10.1093/ forestry/cpi056.

Bonnell TR, Reyna-Hurtado R \& Chapman CA (2011) Post-logging recovery time is longer than expected in an East African tropical forest. Forest Ecology and Management 261: 855-864. doi:10.1016/j. foreco.2010.12.016.

Cámara-Leret R, Frodin DG, Adema F, Anderson C, Appelhans MS, Argent G, Guerrero SA, Ashton P, Baker WJ, Barfod AS, Barrington D, Borosova R, Bramley GLC, Briggs M, Buerki S, Cahen D, Callmander MW, Cheek M, Chen C-W, Conn BJ, Coode MJE, Darbyshire I, Dawson S, Dransfield J, Drinkell C, Duyfjes B, Ebihara A, Ezedin Z, Fu L-F, Gideon O, Girmansyah D, Govaerts R, Fortune-Hopkins H, Hassemer G, Hay A, Heatubun CD, Hind DJN, Hoch P, Homot P, Hovenkamp P, Hughes $M$, Jebb $M$, Jennings L, Jimbo T, Kessler M, Kiew R, Knapp S, Lamei P, Lehnert M, P. Lewis G, Linder HP, Lindsay S, Low YW, Lucas E, Mancera JP, Monro AK, Moore A, Middleton DJ, Nagamasu H, Newman MF, Lughadha EN, Melo PHA, Ohlsen DJ, Pannell CM, Parris B, Pearce L, Penneys DS, Perrie LR, Petoe P, Poulsen AD, Prance GT, Quakenbush JP, Raes N, Rodda M, Rogers ZS, Schuiteman A, Schwartsburd P, Scotland RW, Simmons MP, Simpson DA, Stevens P, Sundue M, Testo W, Trias-Blasi A, Turner I, Utteridge T, Walsingham L, Webber BL, Wei R, Weiblen GD, Weigend M, Weston P, Wilde W de, Wilkie P, Wilmot-Dear CM, Wilson HP, Wood JRI, Zhang L-B \& Welzen PC van (2020) New Guinea has the world's richest island flora. Nature 584: 579-583. doi:10.1038/s41586-020-2549-5.

Colín-Urieta S, Carrillo-Parra A, Rutiaga-Quinones JG, López-Albarrán P, Gabriel-Parra R \& NgangyoHeya M (2018) Natural durability of seven tropical timber species in ground contact at three sites in México. Journal of Tropical Forest Science 30: $75-81$.

Corrià-Ainslie R, Julio Camarero J \& Toledo M (2015) Environmental heterogeneity and dispersal processes influence post-logging seedling establishment in a Chiquitano dry tropical forest. Forest Ecology and Management 349: 122-133. doi:10.1016/j.foreco.2015.03.033.

Curtis JT \& McIntosh RP (1950) The interrelations of certain analytic and synthetic phytosociological characters. Ecology 31: 434-455.

Do HTT, Grant JC, Trinh NB, Zimmer HC, Tran LD \& Nichols JD (2019) Recovery of tropical moist deciduous dipterocarp forest in Southern Vietnam.
Forest Ecology and Management 433: 184-204. doi:10.1016/j.foreco.2018.10.062.

Edwards DP, Tobias JA, Sheil D, Meijaard E \& Laurance WF (2014) Maintaining ecosystem function and services in logged tropical forests. Trends in Ecology and Evolution 29: 511-520. doi:10.1016/j.tree.2014.07.003.

Facelli JM \& Pickett STA (1991) Plant litter: Its dynamics and effects on plant community structure. The Botanical Review 57: 1-32. doi:10.1007/ BF02858763.

Fatem SM, Awang SA, Pudyatmoko S, Sahide MAK, Pratama AA \& Maryudi A (2018) Camouflaging economic development agendas with forest conservation narratives: A strategy of lower governments for gaining authority in the re-centralising Indonesia. Land Use Policy 78: 699-710. doi:10.1016/j.landusepol.2018.07.018.

Fatem SM, Djitmau DA, Ungirwalu A, Wanma OA, Simbiak VI, Benu NMH, Tambing J \& Murdjoko A (2020) Species diversity, composition, and heterospecific associations of trees in three altitudinal gradients in Bird's Head Peninsula, Papua, Indonesia. Biodiversitas 21:3596-3605. doi:10.13057/ biodiv/d210824.

Finnegan L, Pigeon KE \& MacNearney D (2019) Predicting patterns of vegetation recovery on seismic lines: Informing restoration based on understory species composition and growth. Forest Ecology and Management 446: 175-192. doi:10.1016/j. foreco.2019.05.026.

Fleischer K, Rammig A, De Kauwe MG, Walker AP, Domingues TF, Fuchslueger L, Garcia S, Goll DS, Grandis A, Jiang M, Haverd V, Hofhansl F, Holm JA, Kruijt B, Leung F, Medlyn BE, Mercado LM, Norby RJ, Pak B, von Randow C, Quesada CA, Schaap KJ, Valverde-Barrantes OJ, Wang Y-P, Yang X, Zaehle S, Zhu Q \& Lapola DM (2019) Amazon forest response to $\mathrm{CO} 2$ fertilization dependent on plant phosphorus acquisition. Nature Geoscience 12: 736-741. doi:10.1038/s41561-019-0404-9.

Gaveau DLA, Kshatriya M, Sheil D, Sloan S, Molidena E, Wijaya A, Wich S, Ancrenaz M, Hansen M, Broich M, Guariguata MR, Pacheco P, Potapov P, Turubanova S \& Meijaard E (2013) Reconciling forest conservation and logging in Indonesian Borneo. PLoS ONE 8: e69887. doi:10.1371/journal.pone.0069887.

Gaveau DLA, Sloan S, Molidena E, Yaen H, Sheil D, Abram NK, Ancrenaz M, Nasi R, Quinones M, Wielaard N \& Meijaard E (2014) Four decades of forest persistence, clearance and logging on Borneo. PLoS ONE 9: e101654. doi:10.1371/journal. pone.0101654.

Gleason SM, Read J, Ares A \& Metcalfe DJ (2010) Species-soil associations, disturbance, and nutrient cycling in an Australian tropical rainforest. 
Oecologia 162: 1047-1058. doi:10.1007/s00442009-1527-2.

Grussu G, Testolin R, Saulei S, Farcomeni A, Yosi CK, De Sanctis M \& Attorre F (2016) Optimum plot and sample sizes for carbon stock and biodiversity estimation in the lowland tropical forests of Papua New Guinea. Forestry 89: 150-158. doi:10.1093/forestry/cpv047.

Gudiel AA, Nieves SC, Reuter KE \& Sewall BJ (2016) The effect of anthropogenic disturbance on non-native plant species in Madagascar. Journal of Tropical Ecology 32: 543-554. doi:10.1017/ S0266467416000481.

Hughes M, Barber S, Heatubun CD \& Gagul J (2015) Begonia yapenensis (sect. Symbegonia, Begoniaceae), a new species from Papua, Indonesia. European Journal of Taxonomy 2015: 1-6.

Indrawan M, Sumule A, Wijaya A, Kapisa N, Wanggai F, Ahmad M, Mambai BV \& Heatubun CD (2019) A time for locally driven development in Papua and West Papua. Development in Practice 29: 817-823. doi:10.1080/09614524.2019.16099 07.

Johnson DW \& Turner J (2019) Nutrient cycling in forests: A historical look and newer developments. Forest Ecology and Management 444: 344-373. doi:10.1016/j.foreco.2019.04.052.

Kuswandi R, Sadono R, Supriyatno N \& Marsono D (2015) Keanekaragaman struktur tegakan hutan alam bekas tebangan berdasarkan biogeografi di Papua. Jurnal Manusia dan Lingkungan 22: 151159. doi:10.22146/jml.18737.

Ladwig LM, Meiners SJ, Pisula NL \& Lang KA (2012) Conditional allelopathic potential of temperate lianas. Plant Ecology 213: 1927-1935. doi:10.1007/ s11258-012-0087-4.

Laurance WF (2015) Emerging threats to tropical forests. Annals of the Missouri Botanical Garden 100: 71-79. doi:10.1007/978-1-4614-7161-5 5.

Levis C, Costa FRC, Bongers F, Peña-Claros M, Clement $\mathrm{CR}$, Junqueira AB, Neves EG, Tamanaha EK, Figueiredo FOG, Salomão RP, Castilho C V., Magnusson WE, Phillips OL, Guevara JE, Sabatier D, Molino JF, Cárdenas López D, Mendoza AM, Pitman NCA, Duque A, Núñez Vargas P, Zartman CE, Vasquez R, Andrade A, Camargo JL, Feldpausch TR, Laurance SGW, Laurance WF, Killeen TJ, Mendonça Nascimento HE, Montero JC, Mostacedo B, Amaral IL, Guimarães Vieira IC, Brienen R, Castellanos H, Terborgh J, De Jesus Veiga Ca$\operatorname{rim} \mathrm{M}$, Da Silva Guimarães JR, De Souza Coelho L, De Almeida Matos FD, Wittmann F, Mogollón HF, Damasco G, Dávila N, García-Villacorta R, Coronado ENH, Emilio T, De Andrade Lima Filho D, Schietti J, Souza P, Targhetta N, Comiskey JA, Marimon BS, Marimon BH, Neill D, Alonso A, Arroyo L, Carvalho FA, De Souza FC, Dallmeier F,
Pansonato MP, Duivenvoorden JF, Fine PVA, Stevenson PR, Araujo-Murakami A, Aymard CGA, Baraloto C, Do Amaral DD, Engel J, Henkel TW, Maas P, Petronelli P, Cardenas Revilla JD, Stropp J, Daly D, Gribel R, Ríos Paredes M, Silveira M, Thomas-Caesar R, Baker TR, Da Silva NF, Ferreira L V., Peres CA, Silman MR, Cerón C, Valverde FC, Di Fiore A, Jimenez EM, Peñuela Mora MC, Toledo M, Barbosa EM, De Matos Bonates LC, Arboleda NC, De Sousa Farias E, Fuentes A, Guillaumet JL, Møller Jørgensen P, Malhi Y, De Andrade Miranda IP, Phillips JF, Prieto A, Rudas A, Ruschel AR, Silva N, Von Hildebrand P, Vos VA, Zent EL, Zent S, Cintra BBL, Nascimento MT, Oliveira AA, Ramirez-Angulo H, Ramos JF, Rivas G, Schöngart J, Sierra R, Tirado M, Van Der Heijden G, Torre E V., Wang O, Young KR, Baider C, Cano A, Farfan-Rios W, Ferreira C, Hoffman B, Mendoza C, Mesones I, Torres-Lezama A, Medina MNU, Van Andel TR, Villarroel D, Zagt R, Alexiades MN, Balslev H, Garcia-Cabrera K, Gonzales T, Hernandez L, Huamantupa-Chuquimaco I, Manzatto AG, Milliken W, Cuenca WP, Pansini S, Pauletto D, Arevalo FR, Costa Reis NF, Sampaio AF, Urrego Giraldo LE, Valderrama Sandoval EH, Valenzuela Gamarra L, Vela CIA \& Ter Steege H (2017) Persistent effects of pre-Columbian plant domestication on Amazonian forest composition. Science 355: 925-931. doi:10.1126/science.aal0157.

Luize BG, Magalhães JLL, Queiroz H, Lopes MA, Venticinque EM, Leão de Moraes Novo EM \& Silva TSF (2018) The tree species pool of Amazonian wetland forests: Which species can assemble in periodically waterlogged habitats? PLOS ONE 13: e0198130. doi:10.1371/journal.pone.0198130.

Liu JJ \& Slik JWF (2014) Forest fragment spatial distribution matters for tropical tree conservation. Biological Conservation 171: 99-106. doi:10.1016/j.biocon.2014.01.004.

Mansourian S (2017) Governance and forest landscape restoration: A framework to support decision-making. Journal for Nature Conservation 37: 21-30. doi:10.1016/j.jnc.2017.02.010.

Murdjoko A (2013) Recuperation of non-commercial trees in Logged Forest in Southern Papua, Indonesia. Jurnal Manajemen Hutan Tropika 19: 94-102. doi:10.7226/jtfm.19.2.94-102.

Murdjoko A, Jitmau MM, Djitmau DA, Mardiyadi Z, Rumatora A, Mofu WY, Sineri AS, Fatem SM, Worabai D, May NL, Tokede MJ, Warmetan H, Wanggai CB, Wanma JF, Sirami EV, Paembonan JB, Unenor E, Kuswandi R, Lekitoo K, Khayati L, Benu NMH, Tambing J \& Saragih ABS (2020) Heterospecific and conspecific associations of trees in lowland tropical forest of New Guinea. Biodiversitas 21: 4405-4418. doi:10.13057/bio$\mathrm{div} / \mathrm{d} 210960$. 
Murdjoko A, Marsono D, Sadono R \& Hadisusanto S (2016a) Plant species composition and their conspecific association in Natural Tropical Rainforest, South Papua. Biosaintifika: Journal of Biology \& Biology Education 8: 33-46. doi:10.15294/ biosaintifika.v8i1.5217.

Murdjoko A, Marsono D, Sadono R \& Hadisusanto S (2016b) Tree association with Pometia and its structure in logging concession of South Papua forest. Jurnal Manajemen Hutan Tropika 22: 180191.

Murdjoko A, Marsono D, Sadono R \& Hadisusanto S (2017) Recovery of residual forest ecosystem as an impact of selective logging in South Papua: An ecological approach. Biotropia 24: 230-245.

Naniwadekar R, Shukla U, Isvaran K \& Datta A (2015) Reduced hornbill abundance associated with low seed arrival and altered recruitment in a hunted and logged tropical forest. PLOS ONE 10: e0120062.

Nirmal Kumar JI, Patel K, Kumar RN \& Kumar Bhoi R (2011) Forest structure, diversity and soil properties in a dry tropical forest in Rajasthan, Western India. Annals of Forest Research 54: 89-98.

Nopiansyah F, Basuni S, Purwanto Y \& Kosmaryandi N (2017) Forest resource utilization Siberut community and ts implications by the i for the policy Siberut Island Biosphere Reserve. Jurnal Manajemen Hutan Tropika 22: 94-104. doi:10.7226/ jtfm.22.2.94.

Oksanen JF, Guillaume Blanchet F, Friendly M, Kindt R, Legendre P, McGlinn D, Minchin PR, O'Hara RB, Simpson GL, Solymos P, Stevens MHH, Szoecs E \& Wagner H (2019) Package 'vegan.' R package version 3.4.0. (https://cran.r-project.org/web/ packages/vegan/index.html).

Pielou EC (1966) The measurement of diversity in different types of biological collections. Journal of Theoretical Biology 13: 131-144. doi:10.1016/0022-5193(66)90013-0.

Pryde EC, Holland GJ, Watson SJ, Turton SM \& Nimmo DG (2015) Conservation of tropical forest tree species in a native timber plantation landscape. Forest Ecology and Management 339: 96-104.

Ren H, Qin H, Ouyang Z, Wen X, Jin X, Liu H, Lu H, Liu H, Zhou J, Zeng Y, Smith P, Jackson PW, Gratzfeld J, Sharrock S, Xu H, Zhang Z, Guo Q, Sun W, Ma J, Hu Y, Zhang Q \& Zhao L (2019) Progress of implementation on the Global Strategy for Plant Conservation in (2011-2020) China. Biological Conservation 230: 169-178. doi:10.1016/j.biocon.2018.12.030.

Riggs RA, Langston JD, Sayer J, Sloan S \& Laurance WF (2020) Learning from local perceptions for strategic road development in Cambodia's Protected Forests. Tropical Con- servation Science 13: 1940082920903183. doi:10.1177/1940082920903183.

Rosin C (2014) Does hunting threaten timber regeneration in selectively logged tropical forests? Forest Ecology and Management 331: 153-164. doi:10.1016/j.foreco.2014.08.001.

Shannon CE (1948) A mathematical theory of communication. The Bell System Technical Journal 27: 623-656. doi:10.1145/584091.584093.

Sist P, Rutishauser E, Peña-Claros M, Shenkin A, Hérault B, Blanc L, Baraloto C, Baya F, Benedet F, da Silva KE, Descroix L, Ferreira JN, Gourlet-Fleury S, Guedes MC, Bin Harun I, Jalonen R, Kanashiro M, Krisnawati H, Kshatriya M, Lincoln P, Mazzei L, Medjibé V, Nasi R, d'Oliveira MVN, de Oliveira LC, Picard N, Pietsch S, Pinard M, Priyadi H, Putz FE, Rodney K, Rossi V, Roopsind A, Ruschel AR, Shari NHZ, Rodrigues de Souza C, Susanty FH, Sotta ED, Toledo M, Vidal E, West TAP, Wortel V \& Yamada T (2015) The tropical managed forests observatory: A research network addressing the future of tropical logged forests. Applied Vegetation Science 18: 171-174.

Spellerberg IF \& Fedor PJ (2003) A tribute to Claude-Shannon (1916-2001) and a plea for more rigorous use of species richness, species diversity and the "Shannon-Wiener" Index. Global Ecology and Biogeography 12: 177-179. doi:10.1046/ j.1466-822X.2003.00015.x.

Tawer PF, Maturbongs RA, Murdjoko A, Jitmau MM, Djitmau DA, Siburian RHS, Ungirwalu A, Wanma AO, Mardiyadi Z, Wanma JF, Rumatora A, Mofu WY, Sineri AS, Fatem SM, Benu NMH, Kuswandi R, Lekitoo K, Kahyati L \& Tambing J (2020) Vegetation dynamic post-disturbance in Tropical Rain Forest of Bird's Head Peninsula of West Papua, Indonesia. Annals of Silvicultural Research 46. doi:10.12899/asr-2145.

Taylor PG, Cleveland CC, Wieder WR, Sullivan BW, Doughty CE, Dobrowski SZ \& Townsend AR (2017) Temperature and rainfall interact to control carbon cycling in tropical forests. Ecology Letters 20: 779-788. doi:10.1111/ele.12765.

Todou G, Onana JM, Achoundong G, Akoa A, D'Eeckenbrugge GC \& Joly HI (2014) The ecological niche of Dacryodes buettneri (Burseraceae), a timber tree in Central Africa. Journal of Tropical Forest Science 26: 420-427.

Ueda MU, Kachina P, Marod D, Nakashizuka T \& Kurokawa H (2017) Soil properties and gross nitrogen dynamics in old growth and secondary forest in four types of tropical forest in Thailand. Forest Ecology and Management 398: 130-139. doi:10.1016/j.foreco.2017.05.010.

Vitoussek PM \& Sanford RL (1986) Nutrient cycling in moist tropical forest. Annual Review of Ecol- 
ogy and Systematics 17: 137-167. doi:10.1146/ annurev.es.17.110186.001033.

de Winter I, van der Hoek S, Schütt J, Heitkönig IMA, van Hooft P, Gort G, Prins HHT \& Sterck F
(2018) Anthropogenic disturbance effects remain visible in forest structure, but not in lemur abundances. Biological Conservation 225: 106-116. doi:10.1016/j.biocon.2018.03.021. 